Bourke, J. G., Izadi, J., \& Olya, H. (2020). Failure of play on asset disposals and share buybacks: Application of game theory in the international hotel market, Tourism Management, 77, 103984. Doi: 10.1016/j.tourman.2019.103984.

\title{
Failure of Play on Asset Disposals and Share Buybacks: Application of Game Theory in the International Hotel Market
}

\begin{abstract}
The principal purpose of this study has been to investigate the impact of an asset disposal strategy, often coupled with share repurchase programs, by international hotel companies on financial performance, earnings stability and share values. Utilising ratio analysis, stock returns and risk-adjusted measures, the study analyses the differences in performance, stability and market valuations between asset light and more capital intensive hotel companies. The findings of the study indicate negligible differences in most accounting measures of earnings growth and stability between asset light hotel companies and traditional hotel companies with significant holdings of owned or leased property. Drawing on game theory, we conclude that international hotel companies dispose of their assets in an effort to manipulate financial markets and make their stocks more attractive to investors and traders. Notwithstanding the absence of significant differentiation in accounting measures of performance fundamentals, market based measures show that hotel groups failed in the aim of manipulating financial markets. This study recommends avoiding playing this game as dual asset light/share repurchase strategy generated superior risk-weighted returns to that of more capital intensive traditional hotel companies across the period of the study.
\end{abstract}

Keywords: Game theory; international hotel; repurchase strategy; financial performance; riskadjusted measures; market stability

\section{Introduction}

The larger International hotel chains (IHCs) based in the United States and Europe have adopted a strategy, that has led them to dispose of much of their owned real estate, often retaining management agreements on the properties - sale and manage back (SMB's) (Van Ginneken, 2011). Real Estate Investment Trusts (REITs) and Private Equity Funds have been rapidly acquiring major hotel properties and hotel companies released onto the market. 
Bourke, J. G., Izadi, J., \& Olya, H. (2020). Failure of play on asset disposals and share buybacks: Application of game theory in the international hotel market, Tourism Management, 77, 103984. Doi: 10.1016/j.tourman.2019.103984.

According to Bloomberg calculations (Yu, 2013, Yu et al., 2013; 2014) funds have seen their hotel investments triple in value in many cases. REITs have matched the performance of private equity funds. A study by the National Association of Real Estate Investment Trusts found that REITs outperformed private equity over the last full real estate market cycle, in both bull and bear markets, from 1990 to 2007 (NAREIT, 2010).

Sale and leaseback transactions were a precursor to the development of asset disposal strategies pursued by the major US and European hotel chains. The sale and leaseback of real property has been commonplace within the hotel industry as well as other industries in recent decades (Whittaker, 2008). Rapid domestic and international expansion of hotel chains fee based business has been enabled by franchising (Contractor and Kundu, 1998). A strategy that hotel chains, as with earlier sale and lease back financing, share with a number of consumer based businesses across a broad range of industries (Brown et al., 2003; Dev et al., 2002).

Management and ownership structures in the hotel industry are more stratified than is typically the case in other industries (Melissen et al., 2016). Hotel investors entering into a franchise agreement with a major brand often contract for operating services with a hotel management company. The major chains offer property management services on the basis of a percentage of revenues and normally a share of profits that steps up as performance thresholds are reached. Management agreements give operators' a significant element of control over hotel operations without the cyclical risk exposures entailed in ownership or leasing of hotel properties. As IHCs divested of property assets by way of outright disposal or sale and leaseback arrangements, fee-based business models have become the platform for growth. Capital released by adoption of these asset-light strategies has often been returned to investors by way of share buy-backs and special dividends. In contrast to lease rental obligations that appear as a liability on the balance sheet, a management agreement with its associated future income stream is interpreted as an intangible asset (Page, 2007). This difference impacts on the way investors value hotel operators' shares. Nonetheless, some operators' continue to favour the leaseback model that enables them to retain the benefit of all the hotel revenues and profits rather than a relatively lower percentage of both. 
Bourke, J. G., Izadi, J., \& Olya, H. (2020). Failure of play on asset disposals and share buybacks: Application of game theory in the international hotel market, Tourism Management, 77, 103984. Doi: 10.1016/j.tourman.2019.103984.

Large scale share buyback programs have been undertaken concurrently with the significant asset disposals of recent decades. Marriott began a program of asset disposals in earnest following US legislation enabling corporations to repurchase their own shares in 1982. By 2010 it had divested all but a handful of its properties. The UK based IHG group sold the great majority of its stock of approximately 200 owned properties from 2003 to 2013 raising $\$ 10$ billion and returning much of the proceeds to shareholders in the form of share buybacks and special dividends (Roper, 2016). The period of relatively low interest rates that followed the bursting of the dot-com bubble in 1999, coincided with a period of rapid appreciation in the value of stock markets and real estate in general. Hotel properties in prime locations saw spectacular gains in some cases. London's Ritz hotel, for example, quadrupled in value from 2001 to 2005 (Anon, 2010). While IHCs could benefit from sales at top of the market prices, it is also perhaps worthy of note that a substantial element of the gains were used for share repurchases at top of the market prices. Share repurchases reached new peaks in 2007, just before the financial crash, whereas in 2009 when shares were at their cheapest few firms were buying (Economist, 2014).

Following the recovery from the financial crisis of 2007-08, large cap US corporates have accelerated share buybacks reaching new peaks. A Reuters report showed that almost $60 \%$ of the 3,297 publically traded non-financial US companies they examined have bought back their shares since 2010 (Brettel et al., 2015). The purpose of this study is to assess the relative impact of asset disposal and share buyback (ADSB hereafter) strategies on the performance and stability of IHCs, during a period of economic recovery. The study compares the performance of four asset light publically traded hotel companies with a control group comprised of two more capital intensive traditional hotel companies that own or lease a significant element of their hotel room inventory.

To assess the impact of these strategies, the study undertakes an analysis of traditional accounting ratios to measure corporate financial return (return on assets -ROA; return on capital employed - ROCE; net profit margins - NPM and risk (variances of the return variables). Adjusted net profit margins (ANPM) are utilized to assess the proportionate share of hotel earnings accruing to IHCs. Additionally, a market focused measure of risk and return 
Bourke, J. G., Izadi, J., \& Olya, H. (2020). Failure of play on asset disposals and share buybacks: Application of game theory in the international hotel market, Tourism Management, 77, 103984. Doi: 10.1016/j.tourman.2019.103984.

based on the efficient market hypothesis $(\mathrm{Gu}, 1994)$ is employed to measure risk and financial performance. To derive a risk-adjusted performance measure we undertake an analysis based on the Sharpe index

\section{Theoretical Framework}

\section{Game theory}

Game theory explains the rationale of decision making where the stakeholders involved can make strategic decisions to get a better deal when their choices may influence the interests of others (Myerson, 1992). The theory is applied in psychology, politics and sociology. It is applied in economics to explain the decision-making process when stakeholders take decisions under mutual external economic conditions. Gibbons (1992) discussed different models of game theory and identified five elements of the model namely, the players (i.e. stakeholders), information (e.g. records and messages), action (i.e. applied strategy), process (i.e. sequence of actions), and utility (i.e. payoff or profit). This study uses this theory to explain why international hotel groups (players) dispose of their assets and undertake share repurchase programs (action) to manipulate the market by showing improved financial performance metrics (information). Hoteliers by playing this game expect stock appreciation (process) leading to higher financial returns (utility). Among the various types of game theory models (Zhang et al., 2009), this study fits the non-cooperative form that functions based on a perfect Bayesian equilibrium model (Figure 1). In this model, player 1 (hotel groups) take the first action by disposing of assets. Player 1 creates imperfect information, in financially engineering growth in stock values. For player 2 (stock traders), the source of increased performance of the hotel group is not clear. In other words, player 2 takes investment decisions based on growth of share values, which may not necessarily relate to any sustainable increase in income streams or improvement in the underlying fundamentals of financial performance. .

Insert Figure 1 here

Asset Disposals, Sale and Manage-back (SMBs) and Corporate Performance 
Bourke, J. G., Izadi, J., \& Olya, H. (2020). Failure of play on asset disposals and share buybacks: Application of game theory in the international hotel market, Tourism Management, 77, 103984. Doi: 10.1016/j.tourman.2019.103984.

The need to develop brand value has been a key driver of rapid expansion by hotel chains. An asset light structure that utilizes franchising and management agreement overcomes the capital constraints that limit the number of properties that may be brought into the chains portfolio. For the hotel owner the main benefit of a hotel brand is the volume of guests that can be delivered to the property (Mintel, 2016). Hotel chains loyalty programs and corporate agreements are the foundation of its brand value.

The asset sale and manage back strategy pursued by the IHCs has been dubbed as the separation of bricks from brains (Gannon et al., 2010). Arguably, pure real estate investors may have a wider perspective on the best and highest use of land, for example as a site for residential apartment blocks. However, it maybe that the best expert is sometimes an internal property manager (Louko, 2004a). Alternative land use strategies may not always fit well with the objectives of IHCs to secure long-term management contracts on divested hotel properties.

Hotel property differs from real estate holdings in many other businesses insofar as it is an integral part of the customer offering; an essential element of the delivery of accommodation services to customers (Roper, 2016). While hotel property values share the supply and demand dynamics of real estate generally, studies have shown that hotel firm values are much more impacted by wider economic conditions. (Lee and Jang, 2012) found that property prices affected hospitality firms returns only if they were subject to potential asset sales required to overcome financial or liquidity constraints. Even as hotel revenue growth and appreciation of real estate outperformed many other industry sectors in 2014/2015, the Baird/STR hotel stock index recorded precipitous falls in shares prices on market concerns in 2015 over a global economic slowdown and US interest rate hikes (Taylor, 2016).

Asset light strategies may be more appropriate when dealing with a suite of generic properties (Barris, 2002), but may not necessarily be the optimal course of action where assets are integral to a company's competitive position, although the risks may be mitigated by franchising the brand (Kachaner and Whybrew, 2014). The resource based theory of sustainable competitive advantage rests on the ability of a firm to avoid imitation of their resources. This may not be achievable in a world where established distribution channels of hotel franchisors are increasingly challenged by market-dominant online travel agents (OTA's). Mintel reported in 
Bourke, J. G., Izadi, J., \& Olya, H. (2020). Failure of play on asset disposals and share buybacks: Application of game theory in the international hotel market, Tourism Management, 77, 103984. Doi: 10.1016/j.tourman.2019.103984.

2014 that as much as 70\%-80\% of non-affiliated hotel bookings were sourced through OTA's (Mintel, 2014). These OTA's present an alternative choice for hotel owners to traditional chain affiliations. Fee growth from franchising and management agreements in China is also coming under pressure as Chinese groups develop their own International brands.

Conventional wisdom suggests that the asset light course may not be optimal where assets are in short supply, such as is the case with premium hotels located on prime sites. Barriers to entry, including lack of available land, minimise the available supply of these luxury assets. Hilton retains direct ownership of its luxury 'brand builders' including, Hilton Hawaiian Village and the New York Hilton (Hotel Analyst, 2014). In 2016, Hilton announced its intention to spin-off its real estate to a new company to be called Park Hotels and Resorts. The new company will be the second largest publically traded REIT in the lodging industry. The rationale for hotel asset disposals and SMBs is not more efficient space-use or more efficient corporate real estate management (as may be the case with non-property specialist corporations generally), but rather more efficient corporate capital use.

\section{Risk and return trade offs}

The divestiture of real estate risk is a key motivator for adoption of an asset light strategy by IHCs. There is a significant body of research that indicates that stock market returns are negatively correlated with comparatively high levels of real estate ownership (Brounen and Eichholtz, 2005; Louko, 2004b; Roh, 2002). An explanation often cited is that real estate, as a specialized asset, may be undervalued by stock analysts and the market in general. A study of the UK retail sector in 2000 showed the value of real estate holdings for many companies to be greater than their market capitalization (Wainwright, 2000). Hence, the move by many corporations to divest their real property to specialist property managers. In 2012, for example, Woolworths transferred its 69 shopping centre's in Australia and New Zealand into a newlycreated property company, which then listed on the stock market (Williams, 2012). In a study of REITs in the lodging industry that examined both top-line and bottom-line performance of individual hotels (Howton et al., 2012) found that REIT-owned hotels have generated superior profit margins to that of other lodging properties. The researchers attribute the difference to greater cost efficiency attributable to non-distributed operating expenses and fixed charges. 
Bourke, J. G., Izadi, J., \& Olya, H. (2020). Failure of play on asset disposals and share buybacks: Application of game theory in the international hotel market, Tourism Management, 77, 103984. Doi: 10.1016/j.tourman.2019.103984.

Higher profit margins from real estate come with higher market risk, as (Ro and Ziobrowski, 2011) observed in their study of specialised REITs.

As IHCs expand into new, less developed, geographical markets they must balance the risk and returns of different entry mode choices. While equity investment provides a high degree of direct control over assets and brand reputation, for the most part control in the form of management agreements, and not equity investments, has been the preferred model. Graf (2009) noted that equity investors view the entry mode choices of IHCs differently depending on whether the investment was being made in a developed or developing country. Management contracts were valued more highly by investors when associated with expansion into less developed countries. Franchising was the preferred choice of investments for expansion into developed countries.

It has been suggested that lodging property returns are higher and more volatile than returns to other types of real estate (deRoos and Corgel, 1996). Asset light structures, such as management and franchise contracts are considered lower risk investments than leases and ownership. It is thought these models can deliver a better return on assets, lower profit volatility, greater flexibility and higher scale-driven costs savings than direct investments in real property (Kachaner and Whybrew, 2014). The revenue stream from a management or franchise contract is steadier and less variable than that of the actual hotel property where the owner or lessee is actually exposed to the ups and downs of the hotel property cycle (Mintel, 2016). Sohn et al. (2013) in their study spanning the period 2002 to 2010 found that the capital markets assign premiums to firms that go asset light and that decreasing capital intensity elevates firm value. They also concluded that a focus on fee-business was effective in improving profitability, earnings stability and ultimately firm value. In a subsequent study (Sohn et al., 2014), based on the period 2002 to 2011, the researchers concluded that the asset light strategy enables fee based firms to quickly reap the benefits of economic recovery while providing protection from negative shocks when the economy is contracting.

\section{Capital intensity and firm value}


Bourke, J. G., Izadi, J., \& Olya, H. (2020). Failure of play on asset disposals and share buybacks: Application of game theory in the international hotel market, Tourism Management, 77, 103984. Doi: 10.1016/j.tourman.2019.103984.

The managerial finance literature suggests two competing arguments relative to capital intensity with respect to firm risk and performance. High levels of operating leverage can manifest itself in high levels of volatility in earnings due to the presence of relatively high fixed costs. Roh (2002) confirmed that the cash flows derived from restaurant franchising were subject to less volatility than the income of the restaurant itself. Conversely, high operating leverage acts as a profitability multiplier, enhancing earnings once already sunk costs for fixed assets are covered. In distinguishing the effect of operating leverage and financial distress costs in a study of the volatility of equity REIT returns during the financial crisis (Sun et al., 2015) argued that capital structures with higher debt-to-asset ratios were the predominant factor amplifying stock price declines, as compared to commercial real estate in general.

Studies of restaurant franchising (Hsu and Jang, 2009) and capital intensity in the hotel and restaurant industries (Jae Lee and Jang, 2007) found the existence of curvilinear (inverted Ushape relationships) between franchise proportion/capital intensity and firm profitability and intangible value, suggesting the existence of an optimal franchise/capital intensity proportion. The results propose a possibility that franchisors could maximize their profitability and intangible asset value with an optimal franchise/owned asset proportion.

Lee (2008) discussed that until reaching a certain level of internationalisation expanding abroad does not enhance firm value, but after reaching that level, internationalisation begins to increase firm value. Lee speculated that this may be related to the capital-intensive nature of the hotel business. However, as noted by Graf (2009), IHCs generally prefer franchising and management agreements over riskier capital investments for overseas expansion.

\section{Share repurchases}

Sale and leasebacks were primarily used as a financing tool (Barris, 2002). A key motivator for SLBs in the hotel industry was the potential to redirect equity capital tied up in real estate holdings back into further acquisitions of hotel property or fee generating investments in expansion of franchising agreements and management agreements. The transition to an asset light strategy and sale and manage-back transactions has seen a shift towards the use of released capital for share repurchases rather than reinvestment in business expansion. 
Bourke, J. G., Izadi, J., \& Olya, H. (2020). Failure of play on asset disposals and share buybacks: Application of game theory in the international hotel market, Tourism Management, 77, 103984. Doi: 10.1016/j.tourman.2019.103984.

In principle, under the Miller and Modigliani proposition, investors should be indifferent towards returns in the form of dividends or capital gains (Modigliani and Miller, 1958). The proposition, however, relies on assumptions underpinning perfect capital markets such as no transaction costs or differing tax treatments. Corporate boards generally prefer to maintain a steady increase in the annual dividend. Where there is surplus cash to be distributed a special dividend or share buyback provides a greater degree of flexibility then non-recurring increases in annual dividends. Share buybacks, particularly when a program is spread over several years, allow managers the flexibility of timing market purchases. Part of the buyback program can generally be delayed or cancelled without the same adverse reactions that may follow a decrease in dividend pay outs from one year to the next. Investor's capital gains may be taxed at lower rates then dividend income, as is the case in the US and the UK. Consequently, it may benefit investors to receive returns in the form of share buybacks. This form of distribution also allows investors the choice of timing as to when they will realise gains as opposed to the timing of dividend payments which are determined by the corporate board.

A principal rationale for share buybacks is to address what management perceive as a market under-valuation of the organisation's share price. IHG's shares tripled in the period between 2003 and 2011 when it was disposing of much of its hotel property and buying back its shares with the proceeds. This change in strategic direction followed the enactment of legislation in the UK of changes permitting the use of treasury stock, ending the prior UK requirement for repurchased shares to be cancelled, and bringing UK law in line with the situation in the USA. The announcement of a share buyback program can have a positive signalling effect (Comment and Jarrell, 1991; Lie, 2005; Vermaelen, 1981) especially where managers (who are presumed to be acting on insider knowledge) are retaining their own holdings of stocks (Chen et al., 2014).

Many of the finance directors in the UK's leading companies have cited capital restructuring in favour of debt as the primary motive for share buyback programs (Dixon et al., 2008). The tax shield effects of higher gearing can lower the weighted average cost of capital (Dobbs and Rehm, 2005). Higher leverage may also serve to abate investor concerns around agency costs 
Bourke, J. G., Izadi, J., \& Olya, H. (2020). Failure of play on asset disposals and share buybacks: Application of game theory in the international hotel market, Tourism Management, 77, 103984. Doi: 10.1016/j.tourman.2019.103984.

as a higher ratio of interest costs subjects management to tighter financial discipline. This was also a rational for releasing capital via the sale and leaseback route.

While agency costs may potentially reduce as a consequence of capital restructuring, this is not always the case. Where managers are incentivized to increase earnings per share (EPS) a potential conflict arises unless safeguards are in place against rewards being earned as a consequence of eps increases that result from share buybacks. Similar issues arise where management hold significant share options that may benefit from restricting dividend payments. By building up retained earnings the value of options can be increased and a share buyback program can serve to offset the dilutive effects of the exercise of options.

Advocates of stock buybacks see repurchases as providing a greater degree of flexibility in comparison to capital investments and acquisitions; as a signal of confidence by management in the prospects for stock appreciation; an offset to dilution from share-based compensation; and avoidance of mal-investments in projects that do not offer positive net present values (Schneider and Kohlmeyer, 2015). Critics have pointed to the lack of investment in productive assets, research and development and acquisitions. There are concerns around agency problems from executive compensation packages tied to increases in earnings per share. Agency theory also suggests risk aversion by managers playing it safe may explain the preference for stock buybacks over investment. With interest rates at historical lows it has been argued that firms see a better return on buybacks than investing in fixed income securities (Schneider and Kohlmeyer, 2015) and that even borrowing to finance share repurchases is justified because the dividends avoided on repurchased shares exceeds the cost of borrowing.

Notwithstanding the potential conflicts activist investors and share analysts can and do bring pressure on boards to complete share buybacks, even where there is no real indication that stock prices are intrinsically undervalued. Analysts questioned the absence of share repurchases when Starwood Hotels and Resorts Worldwide went two quarters without effecting share buybacks in 2014. This was despite returning dividends, special dividends and share repurchases of almost $£ 10$ billion over the prior ten years (www.Hotelnewsnow.com). The company turned in a credible performance in 2014 in terms of stock price, earnings, new room inventory and pipeline development as well as achieving its goal of asset sales of $\$ 3$ billion 
Bourke, J. G., Izadi, J., \& Olya, H. (2020). Failure of play on asset disposals and share buybacks: Application of game theory in the international hotel market, Tourism Management, 77, 103984. Doi: 10.1016/j.tourman.2019.103984.

over 4 years. Investor pressure, however, following the reversals in stock prices in 2015 ultimately led to the merger talks with competitor groups and the completion of a deal with Marriott International. There continue to be calls from activist investors for mergers between the largest companies in a drive for faster growth and increased earnings (Roper, 2017).

\section{Hypothesis}

The literature review highlights the rationale and motivations for adoption of an ADSB strategy by IHCs. Previous studies have found that sale and leaseback programs in financially stable firms have had a positive impact on corporate performance metrics. Many IHCs have sought to simultaneously divest themselves of perceived real estate risk arising from the ownership or leasing of property while continuing to exercise a high degree of control over assets through the use of management agreements.

The trade-off for IHCs in contracting in size and relinquishing income streams associated with outright ownership or leasing of hotel properties comes with the perceived stability of less risky fee based business in periods of economic contraction. While Sohn et al. (2014) confirmed this outcome, they also found that asset light hotel group's beta was higher during expansion periods, attributing this asymmetric impact to greater sensitivity of asset light firms to economic recovery. In periods of economic expansion, asset light firms are able to expand at a faster pace than traditional IHCs, while continuing to share in the rewards of increased hotel profitability via performance incentive fees in management agreements.

The objective of this study is an empirical examination of the impact of an asset disposal strategy and associated share buyback programs on corporate performance. The study concentrates on testing hypothesis that suggest this strategy will lead to improved performance, albeit with greater instability during expansionary periods, that is in turn recognized in the form of higher market valuations by investors. Our first hypothesis seeks to confirm that this positive trend in the form of return on assets (ROA) is observed in firms adopting a strategy that seeks to significantly reduce their level of investment in tangible hotel assets. 
Bourke, J. G., Izadi, J., \& Olya, H. (2020). Failure of play on asset disposals and share buybacks: Application of game theory in the international hotel market, Tourism Management, 77, 103984. Doi: 10.1016/j.tourman.2019.103984.

H1a - Asset light strategies pursued by IHCs are associated with improved ROA performance during periods of expansion.

H1b - Asset light strategies pursued by IHCs are associated with greater instability in ROA during periods of expansion.

While both asset light IHCs and more capital intensive IHCs utilize share buyback programs as a means of capital restructuring, an asset light strategy presents greater opportunities for reduction of share capital and borrowings secured on hotel property by utilization of the excess proceeds of asset disposals. Traditional IHCs that maintain higher levels of real estate assets will generate less free cash flow than groups pursuing an active program of disposals.

Our second hypotheses seek to confirm that a positive trend in the form of return on capital employed (ROCE) is observed in firms adopting a dual asset light/share repurchase strategy.

H2a - Asset light/share buyback strategies pursued by IHCs are associated with improved ROCE during periods of expansion.

H2b - Asset light/share buyback strategies pursued by IHCs are associated with greater instability in ROCE during periods of expansion.

An asset light strategy entails a focus on fee based revenues. Consequently, the turnover of asset light IHCs is reduced as the gross revenue of owned/leased hotels is replaced with franchising/management fee income. As a lower overall share of previously owned/leased hotel revenues is captured, the net income of asset light IHCs from this source can be expected to reduce. Conversely, the expansion of brands via fee based agreements presents the prospect of significant improvement in the margin of net profit to turnover (NPM), particularly during periods of economic expansion. Additionally, performance incentive fees in management agreements enable asset light IHCs to capture a share of profit growth within hotel operations. Our third hypothesis is formed from these intuitive and theoretical assumptions.

H3a - Asset light strategies pursued by IHCs are associated with improved NPM during periods of expansion. 
Bourke, J. G., Izadi, J., \& Olya, H. (2020). Failure of play on asset disposals and share buybacks: Application of game theory in the international hotel market, Tourism Management, 77, 103984. Doi: 10.1016/j.tourman.2019.103984.

H3b - Asset light strategies pursued by IHCs are associated with greater instability in NPM during periods of expansion.

Traditional IHCs maintain a mix of fee based and owned/leased hotel revenues. The gross revenue recognized by traditional IHCs includes that of their owned/leased hotels. As a proportionally greater overall share of owned/leased hotel revenues is expected to be captured, we would anticipate higher adjusted profit margins for traditional IHCs, as compared with asset light IHCs, when the net profits of both are measured as a percentage of gross hotel revenues (ANPM). Our fourth hypothesis seeks to confirm this expectation.

H4 - Traditional IHCs capture a proportionally greater share of gross hotel receipts as measured by Adjusted Net Profit margins (ANPM).

On the assumption that significant improvement in performance fundamentals is observed during a period of expansion, we expect to see this translated into superior risk-weighted returns for asset light IHCs. Consequently, we derive our final hypothesis as:

H5 - Asset light strategies generate superior risk-weighted returns during periods of expansion to that of more capital intensive traditional hotel companies.

\section{Data and methods}

This study investigates the impact of the ADSB strategy on IHCs performance trends and stock market valuations in the period 2011-2017. The paper seeks an answer to the question of whether an ADSB strategy translates into improved corporate performance and market values.

\section{Data}

The post-crash period has been a relatively benign economic period and much of the larger (but by no means all) asset disposal programs of the asset light IHCs in our sample had been completed by 2011 - the start of our period of study. The ADSB strategy adopted by IHCs is primarily a feature of large capitalization branded chains. There are relatively few major hotel companies with a broad enough international spread, market segment diversification and brand 
Bourke, J. G., Izadi, J., \& Olya, H. (2020). Failure of play on asset disposals and share buybacks: Application of game theory in the international hotel market, Tourism Management, 77, 103984. Doi: 10.1016/j.tourman.2019.103984.

strength to pursue a strategy focused on franchising and management agreements. Construct validity necessitates concentration on relatively few large cap leading brands, Consequently, a purposive sampling technique has been used, based upon identifying multi-brand IHCs (Saunders et al., 2012).

Our study is primarily focused on a portfolio of the IHCs controlling the 15 leading hotel brands, as listed in an MKG hospitality report dated March 2013 published in Global Hotel Perspectives 2014 (Hotel Analyst, 2014). Host Inns has been acquired by BTG Hotels, a Chinese state owned enterprise. Although listed among the leading hotel brands, the company has been excluded from the sample. Recent research has suggested that cultural attitudes towards borrowing and high levels of government shareholdings may account for lower levels of gearing in Chinese listed firms (Tse and Rodgers, 2011). For these reasons and due to the potential distorting effect of Chinese state interventions in stock markets during the period under review, Hyatt hotels has been substituted for Host inns.

The branded hotel market is estimated to account for $53 \%$ of the total hotel market (HotelAnalyst, 2015). The hotel companies in our sample account for approximately $30 \%$ of total branded hotel market in terms of room capacity. Of the companies that control the top 15 brands, 8 are publically traded and one, Best Western, remains a private company. Our sample excludes Best Western (and Hilton Hotels that was privately held until 2013) and segregates 6 listed chains (substituting Hyatt for Home Inns) into two large capitalisation portfolio groups consisting of: Asset light IHCs whose revenues are primarily fee based (defined as owning or leasing less than $1 \%$ of hotel room capacity within their inventory of franchised/operated hotel properties (Table 1, Panel a). More capital intensive traditional IHCs, being companies with greater than $5 \%$ of owned/lease hotel room capacity (Table 1, Panel b).

\section{Insert Table 1 here}

\section{Research methods}

We collected data for our sample of the 4 asset light IHCs and the control group of 2 traditional IHCs for the period 2011 to 2017 . Quarterly accounting data and monthly equity returns were 
Bourke, J. G., Izadi, J., \& Olya, H. (2020). Failure of play on asset disposals and share buybacks: Application of game theory in the international hotel market, Tourism Management, 77, 103984. Doi: 10.1016/j.tourman.2019.103984.

extracted from the Worldscope and Datastream databases. Additional data was obtained from 10k statements or Annual reports as was any data missing from the database to avoid a potential source of sample selection bias. As noted below, the growth index coefficients are not significantly impacted by missing or negative data. Accor is listed on the Paris bourse and reports half-yearly. Consequently, quarterly financial data for this has been calculated by dividing semi-annual reports by two. Accor has been traded in the US via American Depositary Receipts (ADRs) on the OTC market since March 2015.

To measure the relationship of performance (return) and stability (risk) with an asset light strategy the study utilizes three basic accounting measures of performance. ROCE has been preferred over return on equity (ROE) due to the distortionary impact of share buybacks at market value on the book value of shareholders' funds.

ROA - Return on total assets (operating profit/total assets)

ROCE - Return on capital employed (operating profit/total assets-current liabilities)

NPM - Net profit margins (net profit/turnover)

As proposed by Hunter and Coggin (1983) and utilized by Jae Lee and Jang (2007) this study employs profit growth and stability indexes in place of the conventional method of calculating the mean and variances of accounting performance. Equations 1 and 2 used to calculate growth and instability indexes, respectively.

$$
\begin{gathered}
\text { Growth (Equation 1) } \\
\text { Growth }_{\mathrm{ROA}}=b / \overline{R O A}(\mathrm{x} 100) \\
\text { Growth }_{\mathrm{ROCE}}=b / \overline{R O C E}(\mathrm{x} 100) \\
\text { Growth }_{\mathrm{NPM}}=b / \overline{N P M}(\mathrm{x} 100)
\end{gathered}
$$

GrowthROA/ROCE/NPM is the growth index of ROA/ROCE/NPM, b is the raw-score regression coefficient from the simple linear ROA/ROCE/NPM trend regression, and $\overline{R O A} / \overline{R O C E} / \overline{N P M}$ is the arithmetic mean of ROA/ROCE/NPM time series. 
Bourke, J. G., Izadi, J., \& Olya, H. (2020). Failure of play on asset disposals and share buybacks: Application of game theory in the international hotel market, Tourism Management, 77, 103984. Doi: 10.1016/j.tourman.2019.103984.

$$
\begin{gathered}
\text { Instability (Equation 2) } \\
\text { InstabilityROA }={ }^{\sigma}{ }_{\mathrm{ROA}} \sqrt{1-R^{2}} / \overline{R O A} \\
\text { InstabilityROCE }={ }^{\sigma}{ }_{\mathrm{ROCE}} \sqrt{1-R^{2}} / \overline{R O C E} \\
\text { Instability } \\
\end{gathered}
$$

Instability ROA/ROCE/NPM is the instability index of ROA/ROCE/NPM, $\sigma$ $\mathrm{ROA} / \mathrm{ROCE} / \mathrm{NPM}$ is the standard deviation of ROA/ROCE/NPM, and $\mathrm{R}^{2}$ is the coefficient of determination from the simple linear ROA/ROCE/NPM trend regression (Jae, Lee and Jang, 2007). The equation is equivalent to the relative standard error or standard error of estimate divided by the mean.

As Hunter and Coggin (1983) explained this approach is unaffected by negative or zero values in the time series. It does not confuse stable growth or stable retrenchment with variability. The suggested growth statistic multiplied by 100 gives an estimate of the average percent growth in ROA/ROCE/NPM per unit of time (Kim et al., 1989). Additionally, the formulation assesses instability independently of absolute ratio levels. This study bases the simple trend analysis for growth and instability on 28 data points per IHC representing quarterly ROA (ROCE \& NPM) for the seven years from 2011 through 2017.

ANPM - Adjusted net profit margin (Net Profit/Hotel Revenues) is designed to give a relative indication of the impact of an asset light strategy on profit returns from gross hotel revenues. Hotel revenues are calculated by multiplying revenue per available room (RevPar) by the average number of rooms operated by the IHC during the year.

The Sharpe ratio or index provides for the isolation of excess return per unit of total risk taken. This ratio goes beyond measures designed to evaluate portfolio performance within the Capital Assets Pricing Model (CAPM) such as the Treynor and Jensen ratios; and in considering total risk rather than solely systematic risk, is suited to an undiversified portfolio such as our sample which is concentrated within the lodging industry (Kim and Gu, 2003; Mao and Gu, 2007). This study has utilized monthly stock return (MSR) from 2011 to 2017. The ex-post Sharpe 
Bourke, J. G., Izadi, J., \& Olya, H. (2020). Failure of play on asset disposals and share buybacks: Application of game theory in the international hotel market, Tourism Management, 77, 103984. Doi: 10.1016/j.tourman.2019.103984.

index uses actual instead of expected returns to measure historical risk-adjusted returns. The index for the period 2011 to 2017 is calculated based on Equation 3.

$$
S R=\frac{R_{p}-R_{f}}{\sigma_{p}}(\text { Equation } 3)
$$

Where $\mathrm{Rp}$ is the average return of the portfolio (\% change in monthly stock prices) and $\mathrm{Rf}$ is the average monthly return of the risk free rate ( 3 month treasury bills) during the five year period from 2011 to 2017 . The average standard deviation of the portfolio is $\sigma_{p}$.

\section{Results}

\section{Descriptive results}

The mean values of the three profit growth indexes and Instability indexes based on the accounting ratio's ROA, ROCE, NPM and the mean of ANPM are illustrated in Table 2 for asset light and traditional IHCs.

\section{Insert Table 2 here}

Supporting the findings of earlier studies of asset light strategies (e.g., Sohn, 2014) we find distinctive differences in most measures of profit growth or variability. Hypothesis 1a postulated that asset light IHCs would generate greater profit growth as measured by return on assets, through a combination of asset reduction, market expansion and performance incentive fees in a period of economic recovery. The results indicate significantly higher levels of average growth in ROA (based on operating profit) for the Asset Light group compared with the traditional group (0.687 against -1.051). Consequently, the null hypothesis is rejected in respect of H1a. Hypotheses $1 \mathrm{~b}$ postulated that asset light IHCs would experience a greater level of instability in this measure of performance. However, mean variances in quarterly ROA growth of 0.216 against 0.219 were not greatly different. The null hypothesis is accepted in respect of $\mathrm{H} 1 \mathrm{~b}$. 
Bourke, J. G., Izadi, J., \& Olya, H. (2020). Failure of play on asset disposals and share buybacks: Application of game theory in the international hotel market, Tourism Management, 77, 103984. Doi: 10.1016/j.tourman.2019.103984.

Hypothesis $2 \mathrm{a}$ anticipated that the extensive share repurchase /debt retirement programs undertaken by asset light IHCs and the consequent reduction in capital employed would be reflected in greater growth in return on capital employed during this period. The mean growth in ROCE of asset light IHCs at 0.737 was significantly greater than that of the traditional IHC portfolio at -1.392 . Instability of ROCE for asset light IHCs at 0.266 was similar to that of traditional IHCs at 0.320 . The null hypotheses are therefore rejected for both $\mathrm{H} 2 \mathrm{a}$ and $\mathrm{H} 2 \mathrm{~b}$.

Our third hypothesis seeks to test the proposition that asset light IHCs can continue to grow profits as a percentage of revenue (aided by a substitution of fee income for gross hotel receipts in turnover figures and gains on property disposals), even while relinquishing the owner's share of profits from hotel operations in favour of management agreements. Asset light IHCs underperformed traditional IHCs by a factor of 5 times on this measure, recording a mean growth in NPM of 2.896 against growth in NPM for traditional IHCs of 14.907. The difference in the instability of NPM growth was marginal, being 0.815 for asset light IHCs and 0.704 for traditional IHCs. Hypothesis $3 \mathrm{a}$ is consequently rejected but the null hypothesis is not rejected in respect of hypothesis $3 b$.

Hypothesis 4 anticipated the capture by traditional IHCs of a proportionally greater share of gross hotel receipts in the period. With traditional IHCs reporting average net profits as measured by Adjusted Net Profit margins (ANPM) significantly less than asset light IHCs (0.656 versus 2.717$), \mathrm{H} 4$ is rejected.

To measure the risk and return of the both asset light and traditional IHCs, the mean values of the monthly stock return and variances (risk) are provided in Table 3. The monthly stock return of asset light IHCs at 5.04 is ten times that of traditional IHCs at 0.47 . There is a relatively small difference in the variance of monthly stock returns between the two groups.

\section{Insert Table 3 here}

Table 4 presents the Sharpe Ratio as a risk-adjusted performance measure for the two IHC portfolios in the period 2011-2015. The results reflect the superior stock performance of asset light IHCs as measured by the average return earned in excess of the risk-free rate per unit of 
Bourke, J. G., Izadi, J., \& Olya, H. (2020). Failure of play on asset disposals and share buybacks: Application of game theory in the international hotel market, Tourism Management, 77, 103984. Doi: 10.1016/j.tourman.2019.103984.

volatility. In general, the greater the value of the Sharpe ratio, the more attractive the riskadjusted return (Jae Lee and Jang, 2007). The risk adjusted stock returns for traditional IHCs generated significantly lower returns (little above that available from 13 week treasury bills) consistent with the findings of earlier industry studies (Skalpe, 2003). The results confirm the postulation within hypothesis 5 that asset light strategies generate superior risk-weighted returns during periods of expansion to that of more capital intensive traditional hotel companies.

\section{Insert Table 4 here}

\section{Results of inferential statistical analysis}

In Table 5, t-tests are used to determine if statistically significant differences existed in ratio, market and risk-adjusted performance measures. The findings show that there is a single significant difference in the Instability ROCE measure at the 0.05 alpha level. Significant mean differences were not found in monthly stock returns either before or after adjusting for risk. The results of descriptive statistics are somewhat consistent across the accounting and market variance measures in that asset light IHCs had mostly similar levels of financial performance and instability to that traditional IHCs.

\section{Insert Table 5 here}

\section{Discussion and conclusions}

Previous research in strategic hospitality management recognised that the growth of the international hotel industry has been reached through the divestment of real estate portfolios and development of asset light market entry methods (Gannon et al., 2010; Roper, 2017). Using game theory, this study contributes to current knowledge of tourism studies by evaluating the effectiveness of asset light strategies applied by the intentional hotel against traditional IHCs. This study has focused on the relative impact of asset disposal and share buyback strategies on the performance and stability of IHCs in the aftermath of the 2008 financial crisis. The 
Bourke, J. G., Izadi, J., \& Olya, H. (2020). Failure of play on asset disposals and share buybacks: Application of game theory in the international hotel market, Tourism Management, 77, 103984. Doi: 10.1016/j.tourman.2019.103984.

performance of four large capitalisation asset light IHCs with a control group comprised of two large capitalisation capital intensive traditional hotel companies was assessed.

Prior empirical studies have found that a focus on fee-business was effective in improving profitability (Sohn et al., 2013); and asset light hotel groups beta was higher during expansion periods (Sohn et al., 2014). Our findings partially support these earlier studies, showing asset light strategies pursued by IHCs in the five years from 2011 to 2017 are associated with higher growth in most profitability measures. Asset light strategies generate superior risk-weighted returns to that of more capital intensive traditional hotel companies and superior risk-weighted returns are reflected in higher market valuations for asset light IHCs in comparison with their more traditional counterparts. Higher market valuations may be attributable to lower weighted average costs of capital, following capital restructuring via share repurchases, as much as any uplift deriving from the shedding of perceived real estate risk.

Firms adopting asset disposal strategies have opted to return much of the proceeds from downsizing of the asset base to shareholders in the form of share buybacks. To maximise shareholder value, game theory would suggest that firms scale to a size where marginal returns on invested capital are equal to the marginal cost of capital. Alternatives to outright asset disposals and share buybacks pursued by some IHCs, include Hilton's planned transfer of owned hotels to an independently listed REIT as well as creating a separate publicly quoted timeshare business. Similarly, Accor's dual structure, combines both property ownership and hotel and brand management. Joint venture agreements with prospective real estate investors are a further alternative means of driving expansion. These alternative strategies follow the basic premise of portfolio theory insofar as the uncorrelated risk profiles of asset light and capital intensive firms offer the opportunity for diversification of portfolio risk, leaving the choice of risk allocation with investors.

Our findings indicated that asset light IHCs proportionate share of hotel earnings actually increased as compared with traditional IHCs. As new entrants to the international hotel markets begin to make their presence felt, international expansion via SMB's may become more challenging. The big Chinese hotel real-estate groups such as Dalian Wanda Hotels and Resorts are no longer serving as expansion vehicles for Western brands, but are developing properties 
Bourke, J. G., Izadi, J., \& Olya, H. (2020). Failure of play on asset disposals and share buybacks: Application of game theory in the international hotel market, Tourism Management, 77, 103984. Doi: 10.1016/j.tourman.2019.103984.

under their own brands (Mintel, 2016). It is quite possible we may see a rebranding of major Chinese group's foreign-branded hotel properties as the management and franchise contracts on those properties come up for renewal.

Intangible asset values are by nature more volatile than tangible real estate. Findings from comparison of asset light and traditional IHCs revealed that this game is not a sound strategy. As Gintis (2014) discussed lack of information sharing among the agents/stakeholders leads to failure of the game. Hoteliers may need to revisit their strategy in disposing of the assets and share repurchase scheme by playing this game with higher transparency in the process and communicating more complete information. Corporate managers will need to weigh carefully the impact on brand values of the quality of their managed hotel portfolios and the associated income streams. This may require a more strategic approach to asset divestment tailored to specific geographic and market segments in search of an optimal brand mix as the profile of the international hotel industry undergoes change.

This study analyses performance during a period of economic recovery when interest rates have been at historic lows in the United Sates and the European Union. The business cycle may play a significant role in firm performance (Sohn et al., 2014; Singh and Kwansa, 1999; Singh, 2002). Research conducted over the course of a full real estate cycle may provide meaningful insights to the effectiveness of hotel segmentation and internationalization strategies. A study of the relative impact of share buybacks on capital structures and financial leverage is another area that may yield useful results.

While there exists a general consensus among senior corporate executives and the investment community of the potential benefits of an asset light strategy, there remains a debate around how far such a strategy should be pursued (e.g. with respect to flagship properties or economy branded hotels) and whether it is best achieved by transfer of owned hotels to independently listed entities. This debate offers a rich seam of management and accounting research as international competition intensifies and big new players like the Chinese hotel giants enter the arena. Common limitations of a study that focuses on large cap US listed international companies apply equally to this study. The results may not be generalizable to private or nonUS listed hotel groups. Analysis of the performance of IHCs listed on non-US bourses (along 
Bourke, J. G., Izadi, J., \& Olya, H. (2020). Failure of play on asset disposals and share buybacks: Application of game theory in the international hotel market, Tourism Management, 77, 103984. Doi: 10.1016/j.tourman.2019.103984.

the lines of this study) or to smaller cap hotel companies and lodging REITs may add usefully to the existing literature. 
Bourke, J. G., Izadi, J., \& Olya, H. (2020). Failure of play on asset disposals and share buybacks: Application of game theory in the international hotel market, Tourism Management, 77, 103984. Doi: 10.1016/j.tourman.2019.103984.

\section{References}

Barris, R. (2002). Sale-Leasebacks Move to The Forefront: What Is Motivating Buyers and Sellers And What Are Their Preferred Methods? Briefings in Real Estate Finance, 2, 103-112.

Brettel, K., Gaffen, D. \& Rohde, D. (2015). The Cannibalised Company: How The Cult of Shareholder Value Has Reshaped Corporate America. In: Blanten, J. (Ed.) Reuters Special Report. Reuters.

Brounen, D. \& Eichholtz, P. M. A. (2005). Corporate Real Estate Ownership Implications: International Performance Evidence. Journal of Real Estate Finance and Economics, 30, 429445 .

Brown, J. R., Dev, C. S. \& Zhou, Z. (2003). Broadening The Foreign Market Entry Mode Decision: Separating Ownership and Control. Journal of International Business Studies, 473488.

Chen, H.-C., Chen, S.-S., Huang, C.-W. \& Schatzberg, J. D. (2014). Insider Trading and Firm Performance Following Open Market Share Repurchase Announcements. Journal of Business Finance \& Accounting, 41, 156-184.

Comment, R. \& Jarrell, G. A. (1991). The Relative Signalling Power of Dutch-Auction and Fixed-Price Self-Tender Offers and Open-Market Share Repurchases. Journal of Finance, 46, 1243-71.

Contractor, F. J. \& Kundu, S. K. (1998). Modal Choice in A World of Alliances: Analysing Organizational Forms in The International Hotel Sector. Journal of International Business Studies, 29, 325-356.

Deroos, J. A. \& Corgel, J. B. (1996). Measuring Lodging-Property Performance: A Difficult Task with Imperfect Results. Cornell Hotel and Restaurant Quarterly, 37, 20-27.

Dev, C. S., Erramill, M. K. \& S., A. (2002). Brands Across Borders: Determining Factors in Choosing Franchising or Management Contracts for Entering International Markets. Cornell Hotel and Restaurant Quarterly, 43, 91-104. 
Bourke, J. G., Izadi, J., \& Olya, H. (2020). Failure of play on asset disposals and share buybacks: Application of game theory in the international hotel market, Tourism Management, 77, 103984. Doi: 10.1016/j.tourman.2019.103984.

Dixon, R., Palmer, G., Stradling, B. \& Woodhead, A. (2008). An Empirical Survey of the Motivation for Share Repurchases in The Uk. Managerial Finance, 34, 886-906.

Dobbs, R. \& Rehm, W. (2005). The Value of Share Buybacks. Mckinsey Quarterly. Mckinney. Economist, (2014). Business: Asset-Light Or Asset-Right?; Hotels. The Economist. London: The Economist Intelligence Unit N.A., Incorporated.

Economist. (2014). Share Buybacks: The Repurchase Revolution. Economist, 13/09/2014.

Gannon, J., Roper, A. \& Doherty, L. (2010). The Impact of Hotel Management Contracting On Ihrm Practices: Understanding The Bricks and Brains Split. International Journal of Contemporary Hospitality Management, 22, 638-658.

Gibbons, R. (1992). Game Theory for Applied Economists. Princeton, Nj: Princeton University Press.

Gintis, H. (2014). The Bounds of Reason: Game Theory and The Unification of the Behavioural Sciences-Revised Edition. Princeton University Press.

Graf, N. S. (2009). Stock Market Reactions to Entry Mode Choices of Multinational Hotel Firms. International Journal of Hospitality Management, 28, 236-244.

Gu, Z. (1994). Hospitality Investment Risk, Return, And Performance Indexes; A Ten-Year Examination. Hospitality Research Journal, 17, 17-26.

Hotel Analyst (2014). Global Hotel Perspectives 2014. Global Hotel Perspectives. Www.Hotelanalyst.Co.Uk.

Hotelanalyst (2015). Global Hotel Perspectives 2015.

Hotelnewsnow (2014). Buyback Blues Mar Starwood Hotels' Earnings [Online]. Available: Http://Www.Hotelnewsnow.Com/Articles/22463/Buyback-Blues-Mar-Starwood-HotelsEarnings [Accessed 14/08/2016]. 
Bourke, J. G., Izadi, J., \& Olya, H. (2020). Failure of play on asset disposals and share buybacks: Application of game theory in the international hotel market, Tourism Management, 77, 103984. Doi: 10.1016/j.tourman.2019.103984.

Howton, S. D., Howton, S. W., Lee, J. \& Luo, M. (2012). Reits Ownership and Property Performance: Evidence from The Lodging Industry. Journal of Real Estate Portfolio Management, 18, 169-185.

Hsu, L.-T. \& Jang, S. (2009). Effects of Restaurant Franchising: Does an Optimal Franchise Proportion Exist? International Journal of Hospitality Management, 28, 204-211.

Hunter, J. E. \& Coggin, T. D. (1983). Measuring Stability and Growth in Annual Eps. Journal of Portfolio Management, 9, 75-78.

Jae Lee, M. \& Jang, S. (2007). Market Diversification and Financial Performance and Stability: A Study of Hotel Companies. International Journal of Hospitality Management, 26, 362-375.

Kachaner, N. \& Whybrew, A. (2014). When "Asset Light" Is Right [Online]. Available: Https://Www.Bcgperspectives.Com/Content/Articles/Business_Unit_Strategy_Value_Creatio n_Growth_When_Asset_Light_Is_Right/\#Chapter1 [Accessed 25/07/2016].

Kim, H. \& Gu, Z. (2003). Risk-Adjusted Performance: A Sector Analysis of Restaurant Firms. Journal of Hospitality \& Tourism Research, 27, 200-216.

Kim, W. C., Hwang, P. \& Burgers, W. P. (1989). Global Diversification Strategy and Corporate Profit Performance. Strategic Management Journal, 10, 45-57.

Lee, S. (2008). Internationalization of Us Multinational Hotel Companies: Expansion to Asia Versus Europe. International Journal of Hospitality Management, 27, 657-664.

Lee, S. K. \& Jang, S. (2012). The Real Estate Risk of Hospitality Firms: Examining StockReturn Sensitivity to Property Values. International Journal of Hospitality Management, 31, 695-702.

Lie, E. (2005). Operating Performance Following Open Market Share Repurchase Announcements. Journal of Accounting and Economics, 39, 411-436.

Louko, A. (2004a). Competitive Advantage from Operational Corporate Real Estate Disposals. International Journal of Strategic Property Management, 8, 11-24. 
Bourke, J. G., Izadi, J., \& Olya, H. (2020). Failure of play on asset disposals and share buybacks: Application of game theory in the international hotel market, Tourism Management, 77, 103984. Doi: 10.1016/j.tourman.2019.103984.

Louko, A. (2004b). Corporate Real Estate Disposal Impact On Performance Ratios. International Journal of Strategic Property Management, 8, 131-147.

Mao, Z. \& Gu, Z. (2007). Risk-Adjusted Stock Performance. International Journal of Hospitality \& Tourism Administration, 8, 77-98.

Melissen, F., Van Ginneken, R. \& Wood, R.C. (2016). Sustainability Challenges and Opportunities Arising from The Owner-Operator Split In Hotels. International Journal of Hospitality Management, 54, 35-42.

Mintel (2014). Hotel Trends - 2014. Mintel Group.

Mintel (2016). Hotel Chain Strategy - March 2016.

Modigliani, F. \& Miller, M. H. (1958). The Cost of Capital, Corporation Finance and The Theory of Investment. American Economic Review, 48, 261.

Myerson, R. B. (1992). On The Value of Game Theory in Social Science. Rationality and Society, 4(1), 62-73

Nareit (2010). Reits: Real Estate with A Return Premium. Washington, D.C.: National Association of Real Estate Investment Trusts.

Page, T. (2007). 'Asset-Light' - Managing or Leasing? Journal of Retail \& Leisure Property, 6, 97-99.

Ro, S. \& Ziobrowski, A. J. (2011). Does Focus Really Matter? Specialized Vs. Diversified Reits. Journal of Real Estate Finance and Economics, 42, 68-83.

Roh, Y. S. (2002). Size, Growth Rate and Risk Sharing as The Determinants of Propensity to Franchise In Chain Restaurants. International Journal of Hospitality Management, 21, 43-56.

Roper, A. (2016). Interview with Richard Solomons, Ceo Ihg Group. In: Roper, A. (Ed.) Icharm Distinguished Speakers Series. London: London Geller College of Hospitality and Tourism, University of West London. 
Bourke, J. G., Izadi, J., \& Olya, H. (2020). Failure of play on asset disposals and share buybacks: Application of game theory in the international hotel market, Tourism Management, 77, 103984. Doi: 10.1016/j.tourman.2019.103984.

Roper, A. (2017). Vertical Disintegration in The Corporate Hotel Industry. Current Issues in Tourism, 20, 1-6.

Saunders, M., Lewis, P. \& Adrian, T. (2012). Research Methods for Business Students, Essex, England, Pearson Education Limited.

Schneider, D. K. \& Kohlmeyer, J. M. (2015). Stock Buybacks: Is Practice Explained by Management Theory? Journal of Business and Accounting, 8, 64-75.

Singh, A. J. (2002). The Evolution of Innovative Debt and Equity Structures: The Securitisation of Us Lodging Real Estate Finance. Briefings In Real Estate Finance, 2, 139.

Singh, J. A. \& Kwansa, F. A. (1999). Financing The Lodging Industry In The Next Millennium. International Journal of Hospitality Management, 18, 415-25.

Skalpe, O. (2003). Hotels and Restaurants - Are The Risks Rewarded? Evidence from Norway. Tourism Management, 24, 623-634.

Sohn, J., Tang, C.-H. \& Jang, S. (2013). Does The Asset-Light and Fee-Oriented Strategy Create Value? International Journal of Hospitality Management, 32, 270-277.

Sohn, J., Tang, C.-H. \& Jang, S. (2014). Asymmetric Impacts of the Asset-Light and FeeOriented Strategy: The Business Cycle Matters! International Journal of Hospitality Management, 40, 100-108.

Sun, L., Titman, S. D. \& Twite, G. J. (2015). Reit and Commercial Real Estate Returns: A Post-Mortem of the Financial Crisis. Real Estate Economics, 43, 8-36.

Taylor, C. (2016). These Hotel Stocks Could Help Investors Sleep at Night. Fortune Magazine. New York: Fortune Magazine.

Tse, C.-B. \& Rodgers, T. (2011). Can Corporate Tax Shields Explain the Long-Term Borrowing Behaviour of Chinese Listed Firms? International Review of Financial Analysis, 20, 103-112.

Van Ginneken, R. (2011). Asset Light: Common Sense or Construct Impossible? Netherlands: Academy of Hotel Management, Breda University of Applied Sciences, 
Bourke, J. G., Izadi, J., \& Olya, H. (2020). Failure of play on asset disposals and share buybacks: Application of game theory in the international hotel market, Tourism Management, 77, 103984. Doi: 10.1016/j.tourman.2019.103984.

Vermaelen, T. (1981). Common Stock Repurchases and Market Signalling: An Empirical Study. Journal of Financial Economics, 9, 138-83.

Wainwright, S. (2000). Off Balance Sheet Property Ownership Structures: Releasing Capital from Operational Portfolios Through Divestment. Journal of Corporate Real Estate, 2, 330342.

Whittaker, C. (2008). Hotel Operator Motives In UK Sale And Leaseback/Management-Back Transactions. International Journal of Hospitality Management, 27, 641-648.

Williams, K. (2012). Woolworths Spins Off Property Assets. The Australian.

Yu, H.-Y. (2013). Extended Stay Jumps In Debut After \$565 Million Ipo. Bloomberg, $13 / 11 / 2013$.

Yu, H.-Y., Picker, L. \& Brandt, N. (2014). Blackstone's La Quinta Rises After Pricing Stock Sale Low. Bloomberg.

Yu, H.-Y., Picker, L. \& Ruhle, S. (2013). Blackstone’s Hilton Raises \$2.35 Billion In Record Hotel Ipo. Bloomberg.

Zhang, H. Q., Heung, V. C., \& Yan, Y. Q. (2009). Play or Not To Play-An Analysis Of The Mechanism Of The Zero-Commission Chinese Outbound Tours Through A Game Theory Approach. Tourism Management, 30(3), 366-371. 
Bourke, J. G., Izadi, J., \& Olya, H. (2020). Failure of play on asset disposals and share buybacks: Application of game theory in the international hotel market, Tourism Management, 77, 103984. Doi: 10.1016/j.tourman.2019.103984.

Table 1. Asset Light and Traditional IHCs (international hotel chains) information

\begin{tabular}{|c|c|c|c|c|}
\hline Hotel Chain & Symbol Leading Brands & $\begin{array}{c}\text { Hotels } \\
\text { (Thousands) }\end{array}$ & $\begin{array}{c}\text { Rooms } \\
\text { (Thousands) }\end{array}$ & $\begin{array}{l}\% \text { of owned/leased hotel rooms in } \\
2013\end{array}$ \\
\hline
\end{tabular}

Panel a) Asset Light IHCs (<1\% owned/leased hotels)

\begin{tabular}{|c|c|c|c|c|c|}
\hline Choice Hotels International & $\mathrm{CHH}$ & Comfort, Quality & 4 & 328 & $\begin{array}{l}\text { Fee based hotel franchising } \\
\text { company }\end{array}$ \\
\hline InterContinental Hotels Group & IHG & $\begin{array}{l}\text { Holiday Inn, Express by Holiday Inn, } \\
\text { Crowe Plaza }\end{array}$ & 4 & 533 & Less than $1 \%$ owned/leased rooms \\
\hline Marriott International & MAR & $\begin{array}{l}\text { Marriott International, Courtyard by } \\
\text { Marriott }\end{array}$ & 1 & 341 & Less than $1 \%$ owned/leased rooms \\
\hline $\begin{array}{l}\text { Wyndham Worldwide } \\
\text { Corporation }\end{array}$ & WYN & Days Inn, Super8 Motels, Ramada & 5 & 411 & Less than $1 \%$ owned/leased rooms \\
\hline \multicolumn{6}{|c|}{ Panel b) Traditional IHCs (>5\% owned/leased hotels) } \\
\hline Accor & AC.PA & Ibis (Megabrand) & 3 & 182 & $>35 \%$ \\
\hline Hyatt Hotel Corporation & $\mathrm{H}$ & Grand Hyatt, Hyatt Regency, Hyatt Place & 5 & 147 & $>17 \%$ \\
\hline
\end{tabular}

Note: Panel a) identifies the asset light IHCs whose revenues are primarily fee based (defined as owning or leasing less than $1 \%$ of hotel room capacity within their inventory of franchised/operated hotel properties). Panel b) illustrates more capital intensive traditional IHCs, being companies with greater than $5 \%$ of owned/lease hotel room capacity. 
Bourke, J. G., Izadi, J., \& Olya, H. (2020). Failure of play on asset disposals and share buybacks: Application of game theory in the international hotel market, Tourism Management, 77, 103984. Doi: 10.1016/j.tourman.2019.103984.

Table 2. Means of profit growth, instability and adjusted net profit margins (Quarterly data)

\begin{tabular}{|c|c|c|}
\hline Measures & Asset Light IHCs & Traditional IHCs \\
\hline Profit growth means & & \\
\hline Growth return on assets (ROA) & 0.687 & -1.051 \\
\hline Growth return on capital employed (ROCE) & 0.737 & -1.392 \\
\hline Growth net profit margins (NPM) & 2.896 & 14.907 \\
\hline Instability means & & \\
\hline Instability return on assets (ROA) & 0.216 & 0.219 \\
\hline Instability return on capital employed (ROCE) & 0.266 & 0.320 \\
\hline Instability net profit margins (NPM) & 0.815 & 0.704 \\
\hline adjusted net profit margins (ANPM \%) & 2.717 & 0.656 \\
\hline
\end{tabular}

Note: Section a) Profit growth means represents the growth index of three ratios including ROA, ROCE and NPM. These indexes are calculated by dividing the raw-score regression coefficient $(b)$ from the simple linear ROA, ROCE and NPM trend regression by the mean of ROA, ROCE and NPM time-series. Section b) Instability means is the instability index of ROA, ROCE and NPM, which is calculated with standard deviation $(\sigma)$, Coefficient of determination from the simple linear ROA, ROCE and NPM trend regression (R-squared), and mean of ROA, ROCE, and NPM time series. Section C) adjusted net profit margin \% (ANPM) is based on turnover calculated by multiplying revenue per available room (RevPar) by the average number of rooms operated by the IHC during the year. 
Bourke, J. G., Izadi, J., \& Olya, H. (2020). Failure of play on asset disposals and share buybacks: Application of game theory in the international hotel market, Tourism Management, 77, 103984. Doi: 10.1016/j.tourman.2019.103984.

Table 3. Market-based measures for performance and risk (2011-2017)

\begin{tabular}{lcc}
\hline Market measure & Asset Light IHCs & Traditional IHCs \\
\hline Stock returns (SR)\% & 5.040 & 0.470 \\
Variance of monthly stock returns (VMSR) & 0.052 & 0.043
\end{tabular}

Note: SR is based on the monthly percentage changes in stock prices from the previous month; and VSR is the standard deviation of the monthly SR. 
Bourke, J. G., Izadi, J., \& Olya, H. (2020). Failure of play on asset disposals and share buybacks: Application of game theory in the international hotel market, Tourism Management, 77, 103984. Doi: 10.1016/j.tourman.2019.103984.

Table 4. Risk-adjusted performance by the Sharpe Index (2011-2017)

\begin{tabular}{lccccc}
\hline Panel & $\mathrm{R}_{\mathrm{i}}$ & $\mathrm{R}_{\mathrm{f}}$ & $\mathrm{R}_{\mathrm{p}}$ & $\sigma_{\mathrm{i}}$ & Sharpe Index (SI) \\
\hline Asset Light IHCs & 0.050 & 0.004 & 0.046 & 0.052 & 0.888 \\
& & & & & 0.010
\end{tabular}

Note: In the above table, $R_{i}$ is monthly percentage changes in stock price (return) of hotel portfolio i; $R_{f}$ is monthly risk-free rate (monthly mean of 13-week Treasury Bill rates); $R_{p}$ is average excess monthly return on hotel portfolio i $\left(R_{p}=R_{i} R_{f}\right): \sigma_{i}$ is the standard deviation of average monthly return of hotel sector I and $S I$ is the Sharpe Index for the hotel sector i and calculated as follows; $\left(S I=R_{p} / \sigma_{i}\right)$. 
Bourke, J. G., Izadi, J., \& Olya, H. (2020). Failure of play on asset disposals and share buybacks: Application of game theory in the international hotel market, Tourism Management, 77, 103984. Doi: 10.1016/j.tourman.2019.103984.

Table 5. Results of independent samples t-tests

\begin{tabular}{lcc}
\hline Accounting measure & t-statistic & P-value \\
\hline Growth & & \\
Growth return on assets (ROA) & -0.780 & 0.436 \\
Growth return on capital employed (ROCE) & -0.623 & 0.533 \\
Growth net profit margins (NPM) & -1.429 & 0.155 \\
& & \\
Instability & & 0.948 \\
Instability return on assets (ROA) & -0.065 & 0.048 \\
Instability return on capital employed (ROCE) & $2.004^{*}$ & 0.987 \\
Instability net profit margins (NPM) & 0.015 & \\
& & 0.481 \\
Adjusted Net Profit Margin (ANPM) & -0.705 & \\
Market measure & & 0.201 \\
Monthly stock return (MSR) & 1.282 & 0.051 \\
Variance of monthly stock returns (VMSR) & 1.441 & \\
Risk-Adjusted Performance & & 0.194 \\
Sharpe Index & & \\
\hline Note: & & \\
\hline
\end{tabular}

Note: ${ }^{*} \mathrm{p}<0.05$. 
Bourke, J. G., Izadi, J., \& Olya, H. (2020). Failure of play on asset disposals and share buybacks: Application of game theory in the international hotel market, Tourism Management, 77, 103984. Doi: 10.1016/j.tourman.2019.103984.

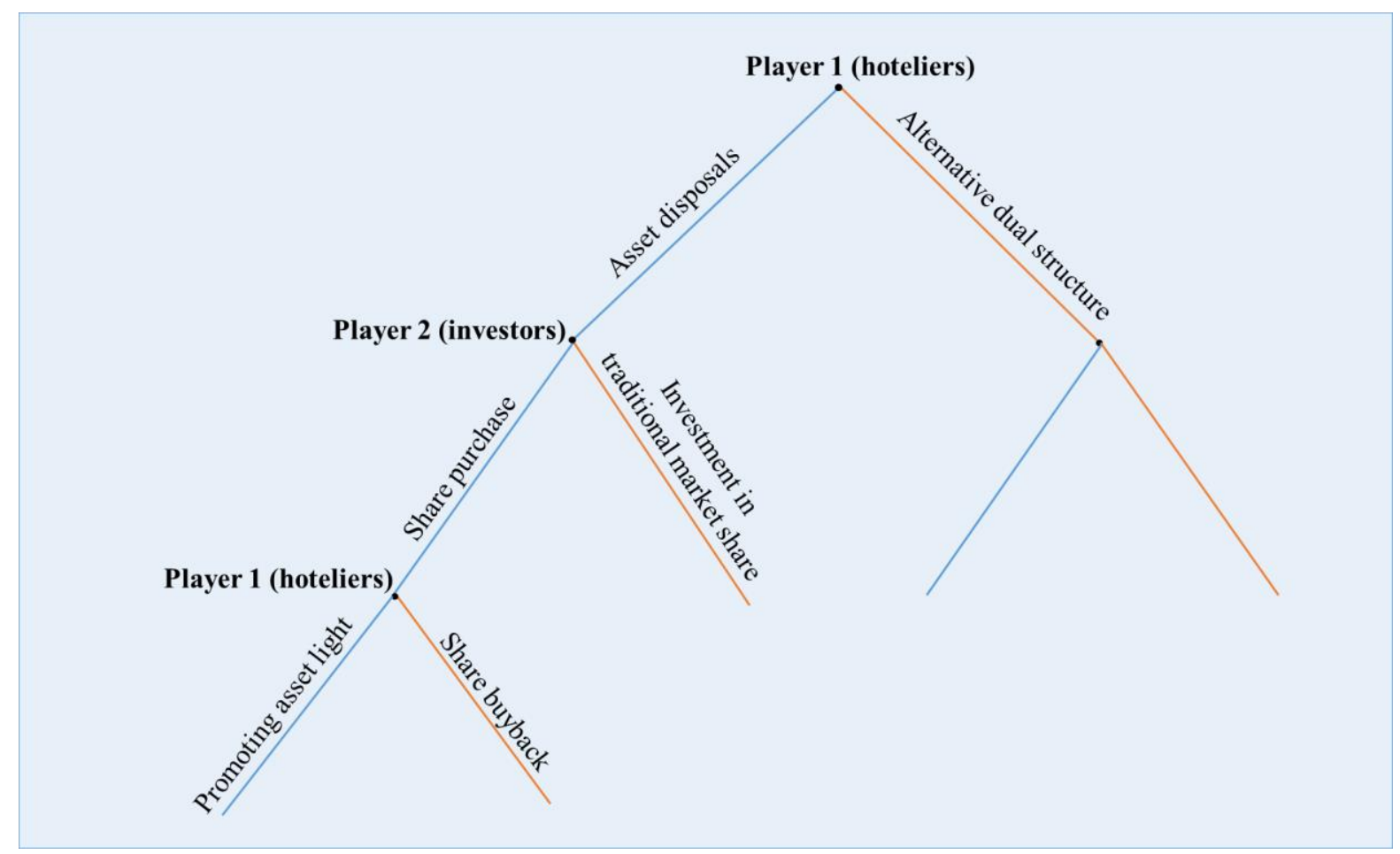

Figure 1. Non cooperative game theory with incomplete information: the perfect Bayesian equilibrium model 